\title{
THE RELATIONSHIP BETWEEN INFORMAL KNOWLEDGE SHARING NETWORK AND INDIVIDUAL LEARNING IN ORGANIZATIONS: DOES THE STRUCTURING OF ACTIVITIES MATTER?
}

Aleša Saša SITAR

Faculty of Economics, Ljubljana

Sabina BOGILOVIĆ

Faculty of Administration, Ljubliana

Marko PAHOR

Faculty of Economics, Ljubliana

UDK: 005.72

Izvorni znanstveni rad

Primljeno: 16. 7. 2018

Capitalizing on organizational network theory, we address the relationship between informal-knowledge-sharing-network characteristics (in-degree and out-degree centrality) and the level of internal and external learning. Specifically, the paper examines differences in the use of various relationships when employees are learning internally or externally and explores the moderating role of the perceived organic structuring of activities. The results show the employees resort to informal-knowledge-generating relationships (informal in-degree) to obtain knowledge internally, whereas, when learning externally, employees rely on informal-knowledge-sharing relationships (informal out-degree) to disseminate the knowledge they obtain from outside the organization. The anticipated moderating role of the organic structuring of activities is not confirmed, holding important implications for both theory and practice.

Keywords: informal knowledge sharing network, internal learning, external learning, organic structuring of activities

Sabina Bogilović, Faculty of Administration, University of Ljubliana, Gosarjeva ulica 5, 1000 Ljubljana, Slovenia. E-mail: sabina.bogilovic@fu.uni-lj.si 
DRUŠ. ISTRAŽ. ZAGREB GOD. 28 (2019), BR. 1, STR. $109-128$

SITAR, A. S., BOGILOVIĆ S., PAHOR, $M$. THE RELATIONSHIP..
Organizations are increasingly studied as networks (Reinholt, Pedersen, \& Foss, 2011) to resolve organizational phenomena (Kilduff \& Brass, 2010b) such as creativity, innovation, knowledge sharing (Burt, 2004; Reinholt et al., 2011; Tsai, 2001), and to explain behaviors closely related to employees' learning (Phelps, Heidl, \& Wadhwa, 2012). To remain competitive, contemporary managers need insights into specific network characteristics that stimulate learning in organizations. However, literature on knowledge networks (Hollenbeck \& Jamieson, 2015; Phelps et al., 2012) is scarce when it comes to findings about the relationship between the organizational network position and specific learning behaviors of individuals (such as internal and external learning). Although the impact of informal network structure on knowledge transfer among business units has been addressed (Reagans \& McEvily, 2003), the specific role played by informal-knowledge-sharing networks for stimulating internal and external learning has yet to be adequately explained.

In addition, the way activities are structured as part of the broader organizational and work design (Mintzberg, 1979) and how they affect the building of informal relationships for internal and external learning has not been examined in the literature. Organizational design research offers some insight into how mechanistic organizational structures are detrimental to certain learning behaviors like idea generation (Keum \& See, 2017) and knowledge exchange, external learning and double-loop learning (Sitar, Pahor, \& Škerlavaj, 2018). Yet it is still not fully clear how organic organizational structures can enhance learning (i.e., internal or external learning) when employees hold a central position in the knowledge network.

In this paper, our aim is to add to the traditional social network theory claim that the advantages of social networks are embedded in social positions (Burt, 1986; Wellman \& Berkowitz, 1988) by exploring how a central position (i.e., in-degree and out-degree centrality) in the knowledge network is associated with employees' internal or external learning. By using a social network approach, we also wish to examine how the structural characteristics of knowledge-sharing networks shape different learning behavior in conditions of organic work designs, specifically the organic structuring of activities (i.e. organic organization). We posit that structural characteristics which stimulate internal learning when activities are organically structured differ from those that support external learning. Applying an actor-level analysis (Borgatti \& Foster, 2003) and by combining the structural and behavioral perspective on learning in organizations (Brass \& Burkhardt, 1993), we consider how the organic structuring of activities as part 
DRUŠ. ISTRAŽ. ZAGREB GOD. 28 (2019), BR. 1 STR. 109-128

SITAR, A. S., BOGILOVIĆ, S., PAHOR, $M$.:

THE RELATIONSHIP... of the work design modifies the relationship between network structure and employees' learning behavior. By bringing together literature on organizational networks, learning in organizations, and organizational/work design, we aim to contribute to better understanding of the differences in relationships that support internal and external learning.

\section{CENTRAL POSITION IN INFORMAL}

\section{INTRAORGANIZATIONAL NETWORKS}

Organizations are today often conceptualized as networks in which different units (e.g., individual employees, teams, departments, or subsidiaries) represent nodes that are connected by some type of social relationship (Brass, Galaskiewicz, Greve, \& Tsai, 2004; Cross \& Cummings, 2004; Hansen, 2002; Ibarra, Kilduff, \& Tsai, 2005; Reinholt et al., 2011; Tsai, 2001). Organizational social network research shows that different structural and relational properties (e.g., centrality, strong/week ties, in/direct ties) can influence performance-related outcomes such as overall job performance ratings (Cross \& Cummings, 2004), productivity (Hansen, 2002; Reagans \& Zuckerman, 2001), and innovation (Tsai, 2001; Tsai \& Ghoshal, 1998). Thus, managers of today's knowledge-intensive organizations need to know which specific network properties (e.g., centrality) among employees can enhance their individual learning in order to stay ahead of the competition.

In organizations, individuals are involved in multiple types of relationships and networks, impacting knowledge creation and transfer (Phelps et al., 2012) via informal (advice, friendship, affective) ties. Since the relationships appearing on organizational charts do not reflect the actual day-to-day practice of how work is accomplished (Han, 1996), informal networks coexist in organizations and can influence employees' individual work and learning. As such, work-related tasks are embedded within informal networks of communication, advice, and friendship relationships (Kilduff \& Brass, 2010b). Informal networks offer better support for knowledge sharing in organizational settings. Particularly communities of practice, which are built mostly independently of the formal structure, provide support for knowledge exchange (Aljuwaiber, 2016). For example, Reagans and McEvily's (2003) research on knowledge-based theory recognized that the ability to transfer knowledge in organizations is critical for several organizational processes and outcomes, thus confirming the role of informal network structure in knowledge transfer where employees share knowledge with coworkers in the form of advice, on-the-job help, new knowledge and collaboration. Accordingly, in this paper we shall explore the importance of infor- 
DRUŠ. ISTRAŽ. ZAGREB GOD. 28 (2019), BR. 1, STR. $109-128$

SITAR, A. S., BOGILOVIĆ S., PAHOR, $M$. THE RELATIONSHIP.. mal relationships among employees and their link with individual learning behavior.

To explore the role played by informal relationships, degree centrality is a measure that is commonly used in organizational knowledge network research (Carpenter, Li, \& Jiang, 2012). Degree centrality may be a good indicator of informal status in organizations (Krackhardt, 1992) because individuals in the central position of a knowledge network are 'in the thick of things' and are the focal points of communication (Freeman, 1978; Reinholt et al., 2011). They thus can have more access to information, innovation, stimulating creativity, and knowledge sharing (e.g., Baldwin, Bedell, \& Johnson, 1997; Brass, 1984; Ibarra \& Andrews, 1993; Burt, 2004; Reinholt et al., 2011; Tsai, 2001). As Freeman (1978) explains, degree centrality can be further broken down into two types: direct informal ties that a focal individual establishes with other individuals in the social network (i.e., out-degree centrality) and direct informal ties that a focal individual has with other individuals in the social network (i.e., in-degree centrality). As such, in-degree centrality is the number of other people who choose that person in a particular relationship; it is the number of incoming ties. Out-degree centrality is the number of people chosen by the person; hence, the number of outgoing ties. In-degree centrality vs. out-degree centrality in an informal-knowledge-sharing network are also defined as knowledge inflows vs. knowledge outflows representing knowledge-collecting vs. knowledge-donating behavior (Cavaliere, Lombardi, \& Giustiniano, 2015). Taken together, in this paper we will explore how informal in-degree and out-degree centrality are connected to learning (i.e., external and internal).

\section{In-degree centrality and internal learning}

Employees of organizations learn by either accumulating internal knowledge in the organization or gathering and integrating external information (Shin, Picken, \& Dess, 2017). The literature refers to these two types of organizational learning as internal or external learning (Huber, 1991; Levitt \& March, 1988). Internal learning starts with individuals asking for knowledge and sharing the internal knowledge with their co-workers (Simon, 1991). It includes learning from sources of knowledge internal to the organization (Kessler, Bierly, \& Gopalakrishnan, 2000) such as a personal or telephone conversation with co-workers, teamwork, intranet, emails among co-workers, internal seminars and training programs, internal meetings, internal documents, etc. (Davenport \& Prusak, 1998). Thus, besides formal relationships, internal learning requires a large number of informal relationships in order for employees to obtain certain knowledge from their co-workers via different channels. 
DRUŠ. ISTRAŽ. ZAGREB GOD. 28 (2019), BR. 1 STR. $109-128$

SITAR, A. S., BOGILOVIĆ, S., PAHOR, $M$.: THE RELATIONSHIP...

In-degree centrality, as part of the informal relationships among colleagues, is crucial for internal learning, while individuals with high in-degree centrality are sought after for their companionship and work-related input (Klein, Lim, Saltz, \& Mayer, 2004). Moreover, coworkers often go to for advice (advice centrality) and consider as a friend (friendship centrality) individuals with high in-degree centrality (Klein et al., 2004). Closer friends are likely to have a larger number of conversations and disclose more information (Bhardwaj, Qureshi, Konrad, \& Lee, 2016) and are therefore more likely to be engaged in learning behavior with each other. In addition, Lazega (1992) explains cognitive status as a special kind of status that is measured by in-degree centrality in advice networks, which is often treated as a proxy for learning networks. Hence, high in-degree centrality in a knowledge-sharing network will stimulate internal learning by enabling employees to source knowledge from colleagues based on their friendship centrality and advice centrality position in the intraorganizational knowledge network. In-degree centrality (Aljuwaiber, 2016) will also support internal learning by providing employees with on-the-job help and new knowledge from coworkers through an incoming relationship. Thus, the more the employee is a knowledge receiver with informal incoming relationships, the higher is their level of internal learning. We therefore expect that the higher the individual's in-degree in an informal-knowledge-sharing network, the more likely it is that employee will engage in internal learning, and thus propose:

H1: The in-degree centrality of an employee in an informal network is positively related to internal learning.

\section{Out-degree centrality and external learning}

External learning begins by identifying new knowledge from different outside sources such as customers, competitors, suppliers, universities, research centers, and other industries, which is then transferred across the organization (Dahlander, O'Mahony, \& Gann, 2016; Kessler et al., 2000). It encompasses learning from external sources of knowledge found and derived from the organizational environment, along with knowledge sourced from different literature (e.g., books, journals, papers), the Internet (e.g., forums, online debates), etc. (Davenport \& Prusak, 1998). External learning based on knowledge lying outside the organization is particularly valued in $R \& D$ organizations that are under constant pressure to provide innovation (Fey \& Birkinshaw, 2005). It starts with sourcing outside knowledge and then transferring the acquired 
DRUŠ. ISTRAŽ. ZAGREB GOD. 28 (2019), BR. 1, STR. 109-128

SITAR, A. S., BOGILOVIĆ S., PAHOR, $M$. THE RELATIONSHIP.. such, we propose the role of informal intra-organizational networks might vary for external learning and for internal learning.

As mentioned, out-degree centrality is defined as the number of outgoing informal ties, more precisely direct informal ties, that a focal individual establishes with other individuals in the social network (Freeman, 1978). High out-degree centrality means employees are more likely to share external knowledge they obtain since they are more inclined to actively seek out members to discuss relevant work issues (Ho \& Pollack, 2014). Ho and Pollack (2014) found that entrepreneurs' harmonious passion is positively related to their outdegree centrality, which indicates that individuals with a high out-degree are more likely to proactively embrace the opportunities in networking groups to share knowledge. In addition, a high out-degree position increases both the amount and diversity of resources an individual can obtain and share (Stam \& Elfring, 2008). A high measure of out-degree centrality thus indicates external learning is supported by outgoing relationships used for sharing externally obtained knowledge in the form of advice, on-the-job help, or new knowledge with their co-workers. Furthermore, "employees high in network centrality are not only in a position to obtain access to a great amount of knowledge, but are also seen as attractive knowledge-sharing partners by others" (Reinholt et al., 2011, p. 1279). Thus, the more the employee is a knowledge sender via informal outgoing relationships, the higher is their level of external learning. We therefore expect that the higher the individual's out-degree centrality in an informal-knowledge-sharing network, the more likely they are to engage in external learning.

H2: The out-degree centrality of an individual in an informal network is positively related to external learning.

\section{The moderating role of the organic structuring of activities}

Work design can be explained as the content of how organizations design tasks, activities, relationships, and responsibilities of an individual's work (Parker, 2014). It is strongly related to the structuring of activities (formalization, specialization, standardization of activities) where different organizational designs are found to influence external learning. Accordingly, the structuring of activities represents part of work design on the individual level as an element of broader organization and work design (Mintzberg, 1979). Doreian and Conti's (2012) research shows that work design impacts the social relations formed in organizations. When work design defines tasks well and is more formalized, it can be organized serially, with lim- 
DRUŠ. ISTRAŽ. ZAGREB GOD. 28 (2019), BR. 1 STR. 109-128

SITAR, A. S., BOGILOVIĆ, S., PAHOR, $M$.: THE RELATIONSHIP... ited communication, whereas if work is ambiguous and less formalized, it requires interaction and is organized collaboratively (Repenning, Kieffer, \& Repenning, 2018). Furthermore, research on work design acknowledges that certain work designs, especially a less centralized organizational structure, can stimulate greater knowledge sharing (Wang \& Noe, 2010) and thus intensive employees' learning (Parker, 2014). We therefore predict that work design based on the extent to which activities at work are structured (e.g., organic structure of activities) might influence how informal social relationships (i.e., in-degree centrality and out-degree centrality) stimulate certain employees' learning behavior (i.e., internal learning and external learning).

Organically designed jobs and working activities indicate that decision-making is decentralized; employees pay greater attention to developing informal relationships, multidirectional communication and integration processes to coordinate work activities (Aiken \& Hage, 1971; Bruns \& Stalker, 1961). We thus predict that an organic structuring of work activities will stimulate informal social relationships (i.e., in-degree centrality and out-degree centrality). Organic structures namely allow employees to establish more efficient communication between different management levels (Winter, 1994) and are more suitable for socialization based on Nonaka and Takeuchi's (1995) model of knowledge conversions. Informal social relationships are also more enhanced in an organic structuring of work activities. The increased emphasis on decentralized decision-making "allows employees closest to internal tacit knowledge greater participation in decision-making processes, highlighting their roles in improving products and processes through facts and knowledge" (Huang, Rode, \& Schroeder, 2011, p. 1106). Second, learning occurs more easily within organic structures while employees recognize their interdependence and are thus willing to share information to achieve the firm's vision and sustain its effectiveness (Fiol \& Lyles, 1985; Slater \& Narver, 1995; Vera \& Crossan, 2004). In addition, empirical evidence shows that an organic organizational structure stimulates learning (Huang et al., 2011; Martínez-León \& Martínez-García, 2011). We therefore predict that if employees perceive the structuring of activities as more organic, they will rely more on informal relationships (i.e., in-degree centrality and out-degree centrality) to communicate, socialize, and share their knowledge, with this then stimulating their internal learning behavior. Thus, we hypothesize:

H3a: The organic structuring of activities moderates the positive relationship between an individual's in-degree centrality in an informal network and internal learning such that it strengthens the relationship. 
DRUŠ. ISTRAŽ. ZAGREB GOD. 28 (2019), BR. 1, STR. 109-128

SITAR, A. S., BOGILOVIĆ, S., PAHOR, $M$. THE RELATIONSHIP..

$\rightleftharpoons$ FIGURE 1

Relationships between the focal constructs
We predict the same mechanism will emerge in the outdegree and external learning relationship. In conditions of less formalized work, enhanced informal channels may also be useful for employees to share externally obtained knowledge across the organization (Huang et al., 2011) because an organic structure is not only suitable for socialization but also for externalization (Martínez-León \& Martínez-García, 2011). On this basis, we propose the positive relationship between out-degree centrality in an informal network and external learning will strengthen if employees perceive the structuring of activities is more organic. We thus hypothesize:

H3b: The organic structuring of activities moderates the positive relationship between an individual's out-degree centrality in an informal network and external learning such that it strengthens the relationship.

Figure 1 presents our proposed hypotheses.

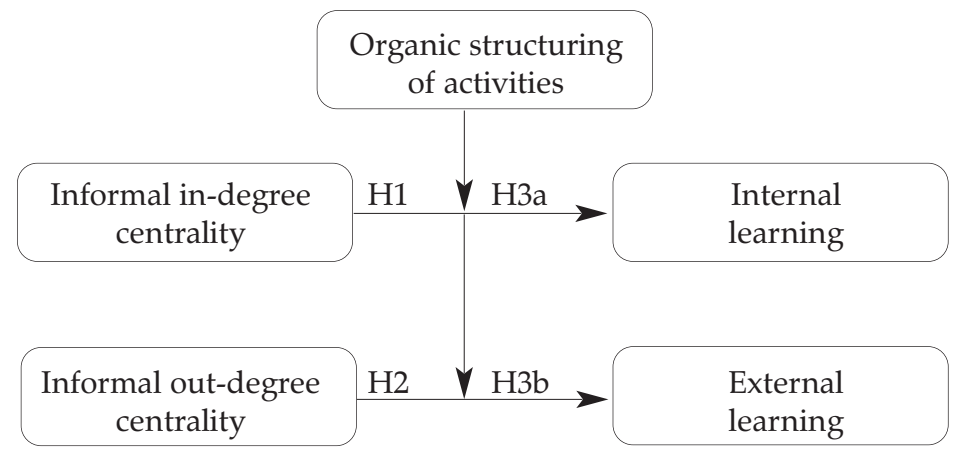

\section{METHODS}

\section{Data collection and procedures}

A large Slovenian company from the coatings industry known for investing in R\&D and employee learning was selected for the research site. Preliminary interviews with company representatives (human resource manager, total quality manager, and R\&D manager) confirmed that the company and employees spend a considerable amount of time on knowledge-related activities (creating, searching, sharing, using knowledge). We therefore developed and sent out a questionnaire to 157 employees in 12 different departments (6 R\&D units, 4 production units, technology and quality control). The departments were chosen together with company representatives due to the expected differences in the various employees' learning behavior (R\&D involved in external learning, production in internal learning) and work design (R\&D with 
DRUŠ. ISTRAŽ. ZAGREB GOD. 28 (2019), BR. 1 STR. $109-128$

SITAR, A. S., BOGILOVIĆ, S., PAHOR, $M$.: THE RELATIONSHIP...

\section{Measures}

a less structured work design and production with a more structured work design). The questionnaire was distributed online and on paper for those employees without access to a computer. Overall, 100 employees responded to the questionnaire, making the response rate $64 \%$.

All variables were self-reported, a common approach to this type of research. As suggested in the literature (Kilduff \& Krackhardt, 1994), we relied on individuals' perceptions of social networks as a measure of social ties. Perceptual measures were applied for internal and external learning as they are found to provide important evidence that learning/knowledge transfer has occurred within or between organizations (Easterby-Smith, Lyles, \& Tsang, 2008). Regarding the respondents, $63 \%$ were male and the average age was 42 years. Individual measures obtained from organizational network analysis were used in regression models following Ibarra (1992). The assumptions of regression analysis about the linearity of the dependent variable, a normal distribution of errors, and non-significant multicollinearity among the independent variables were checked.

Given that implicit and explicit knowledge were obtained in different ways, we included items to account for learning both types of knowledge.

Internal learning. We asked employees how often they obtain knowledge through a face-to-face conversation or a phone call with a co-worker, in internal project and other documents, when they solve problems together during team meetings, when attending internal seminars, training, and education programs and while discussing problems at internal meetings. Five items were derived from the literature to reflect different internal sources of knowledge (Davenport \& Prusak, 1998). The items were measured on a five-point scale, where $0=$ "never," 1 = "a few times per year," 2 = "a few times per month," 3 = "a few times per week," and 4 = "daily." A sample item is "Face-to-face conversation or a phone call with a co-worker". Factor analysis confirmed a single measure for internal learning $(\alpha=0.77)$.

External learning. The employees were asked how often they obtain knowledge on the Internet, by asking a supplier, buyer, or competitor, when searching for knowledge in different literature (books, journals, papers, etc.) and while following discussions on forums and debates on the Internet. Four items were used to reflect different external knowledge sources (Davenport \& Prusak, 1998). These items were measured on the same five-point scale as above. A sample item is "I search for knowledge on the Internet". Factor analysis confirmed a single measure for external learning $(\alpha=0.90)$. 
DRUŠ. ISTRAŽ. ZAGREB GOD. 28 (2019), BR. 1, STR. 109-128

SITAR, A. S., BOGILOVIĆ, S., PAHOR, $M$. THE RELATIONSHIP..
In-degree was calculated from the number of individuals from whom a certain person receives advice, on-the-job help, and new knowledge, hence, from the number of a certain individual's incoming informal relationships, representing the level of support they receive from co-workers in the form of knowledge. The higher the number of incoming informal relationships, the higher the in-degree measure.

Out-degree was calculated from the number of outgoing relationships, indicating to whom a certain person gives advice, on-the-job help and new knowledge, representing that person's level of influence on their co-workers through knowledge sharing. The higher the number of outgoing informal relationships, the higher the out-degree measure.

Organic structuring of activities was measured on the individual employee level with a four-item scale $(\alpha=0.90)$ relating to three structural characteristics of the formalization, standardization, and specialization of work (Pugh, 2003; Pugh, Hickson, Hinings, \& Turner, 1968). Response options ranged from $1=$ "completely disagree" to $5=$ "completely agree". We used a reverse scale to measure the organic structuring of activities. A sample item is "My work is specified in detail".

We also controlled for gender, age, and two department dummies (R\&D, production) to control for the impact of social proximity.

\section{RESULTS}

\section{() TABLE 1}

Descriptive statistics and correlations among variables used in the research $a, b$
Descriptive statistics for all variables analyzed in the study are presented in Table 1, with coefficient alphas for multi-item scales on the diagonal in parentheses. In order to test our hypotheses, we then conducted two separate regression analyses that are shown in Tables 2 and 3.

\begin{tabular}{|c|c|c|c|c|c|c|c|c|c|c|c|c|}
\hline & Variable & $M$ & $S D$ & 1 & 2 & 3 & 6 & 7 & 8 & 9 & 10 & 11 \\
\hline 1 & Gender & 0.349 & 0.479 & - & & & & & & & & \\
\hline 2 & R\&D unit & 0.547 & 0.500 & $0.388^{* *}$ & - & & & & & & & \\
\hline 3 & Production unit & 0.340 & 0.476 & $-0.525^{* *}$ & $-0.788^{* *}$ & - & & & & & & \\
\hline 6 & Age & 42.160 & 8.590 & -0.053 & $-0.194^{*}$ & 0.154 & - & & & & & \\
\hline 7 & Organic & 3.017 & 1.009 & -0.007 & $0.253^{* *}$ & $-0.291^{* *}$ & 0.040 & $(0.90)$ & & & & \\
\hline 8 & In-degree centrality & 0.234 & 0.139 & -0.182 & $-0.372^{* *}$ & $0.425^{* *}$ & 0.061 & $-0.546^{* *}$ & - & & & \\
\hline 9 & Out-degree centrality & 0.237 & 0.192 & -0.113 & -0.188 & 0.132 & $0.194^{*}$ & -0.193 & $0.635^{* *}$ & - & & \\
\hline 10 & Internal learning & 1.390 & 0.764 & 0.007 & $-0.219^{*}$ & 0.094 & 0.185 & 0.089 & $0.298^{* *}$ & $0.368^{* *}$ & * $(0.77)$ & \\
\hline 11 & External learning & 1.058 & 0.868 & 0.085 & $0.325^{* *}$ & $-0.344^{* *}$ & -0.104 & $0.421^{* *}$ & -0.124 & 0.163 & $0.495^{* *}$ & * $(0.90)$ \\
\hline
\end{tabular}

a $\mathrm{n}=100$

$\mathrm{b}$ Coefficient alphas are on the diagonal in parentheses

Statistical significance levels: ${ }^{* *} p<0.01,{ }^{*} p<0.05$

First, we conducted a hierarchical ordinary least squares (OLS) regression to test whether informal in-degree is positively related to informal learning (H1) and whether the organic structuring of activities (H3a) moderates this relation- 
DRUŠ. ISTRAŽ. ZAGREB GOD. 28 (2019), BR. 1 STR. $109-128$

SITAR, A. S., BOGILOVIĆ, S., PAHOR, $M$.: THE RELATIONSHIP..

(1) TABLE 2

Regression analyses results for internal learning as the dependent variable ship. In step 1, we entered the control variable (i.e., gender, R\&D department, production department, age, informal outdegree); in step 2, we added informal in-degree and the organic structuring of activities. In-degree was found to be positively related to internal learning $(\beta=0.26$, se $=2.49, p<0.10)$, marginally supporting Hypothesis 1 (see Table 2, step 2). In step 3 , we added the interaction between informal in-degree and the organic structuring of activities $(\beta=-1.65$, se $=1.72$, $n s g$.$) , although the interaction had no statistical significance.$ Thus, Hypothesis $3 a$ is rejected. Moreover, from Table 2 step 3 we can see that in-degree was still marginally positively related to internal learning $(\beta=0.26$, se $=2.49, p<0.10)$ even though we put the interaction between informal in-degree and the organic structuring of activities.

\begin{tabular}{|c|c|c|c|c|c|c|c|c|c|c|c|c|}
\hline \multirow[b]{2}{*}{ Variables } & \multicolumn{4}{|r|}{ Step 1} & \multicolumn{4}{|c|}{ Step 2} & \multicolumn{4}{|c|}{ Step 3} \\
\hline & $b$ & $S E$ & $\beta$ & $t$ & $b$ & $S E$ & $\beta$ & $t$ & $b$ & $S E$ & $\beta$ & $t$ \\
\hline Gender & 0.13 & 0.17 & 0.08 & 0.78 & 0.11 & 0.17 & 0.07 & 0.63 & 0.15 & 0.18 & 0.10 & 0.86 \\
\hline R\&D department & $-0.38+$ & 0.22 & -0.25 & -1.69 & $-0.41 \dagger$ & 0.22 & -0.27 & -1.82 & $-0.43+$ & 0.22 & -0.28 & -1.90 \\
\hline Production unit & -0.10 & 0.25 & -0.06 & -0.38 & -0.23 & 0.27 & -0.14 & -0.86 & -0.25 & 0.27 & -0.16 & -0.94 \\
\hline Age & 0.01 & 0.01 & 0.06 & 0.63 & 0.01 & 0.01 & 0.08 & 0.81 & 0.01 & 0.01 & 0.08 & 0.82 \\
\hline Out-degree centrality & $4.54^{* *}$ & 1.08 & 0.39 & 4.20 & 2.24 & 1.57 & 0.19 & 1.43 & 2.27 & 1.57 & 0.20 & 1.45 \\
\hline Organic & & & & & 0.04 & 0.07 & 0.05 & 0.52 & 0.17 & 0.15 & 0.22 & 1.09 \\
\hline In-degree centrality & & & & & $4.88 t$ & 2.49 & 0.26 & 1.96 & $10.47 t$ & 6.34 & 0.56 & 1.65 \\
\hline In-degree centrality*org & & & & & & & & & -1.65 & 1.72 & -0.37 & -0.96 \\
\hline$R^{2}$ & & 0.23 & & & & 0.26 & & & & 0.27 & & \\
\hline$\Delta R^{2}$ & & 0.23 & & & & 0.03 & & & & 0.01 & & \\
\hline$F(d f)$ & & $5.59^{*}$ & * $(96)$ & & & $4.66^{* *}$ & (93) & & & $4.18^{* *}$ & (92) & \\
\hline
\end{tabular}

${ }^{* * *} p<0.001,{ }^{* *} p<0.01,{ }^{*} p<0.05, p \dagger<0.1$

\begin{tabular}{|c|c|c|c|c|c|c|c|c|c|c|c|c|}
\hline \multirow[b]{2}{*}{ Variables } & \multirow[b]{2}{*}{$b$} & \multirow[b]{2}{*}{$S E$} & \multicolumn{2}{|c|}{ Step 1} & \multicolumn{4}{|c|}{ Step 2} & \multicolumn{4}{|c|}{ Step 3} \\
\hline & & & $\beta$ & $t$ & $b$ & $S E$ & $\beta$ & $t$ & $\bar{b}$ & $S E$ & $\beta$ & $t$ \\
\hline Gender & -0.23 & 0.20 & -0.13 & -1.18 & -0.05 & 0.19 & -0.03 & -0.29 & -0.03 & 0.19 & -0.02 & -0.15 \\
\hline R\&D department & 0.26 & 0.26 & 0.15 & 1.00 & 0.30 & 0.24 & 0.17 & 1.23 & 0.26 & 0.24 & 0.15 & 1.08 \\
\hline Production unit & $-0.62^{*}$ & 0.29 & -0.34 & -2.11 & -0.19 & 0.29 & -0.11 & -0.67 & -0.23 & 0.29 & -0.13 & -0.78 \\
\hline Age & -0.01 & 0.01 & -0.06 & -0.64 & -0.01 & 0.01 & -0.14 & 1.52 & -0.01 & 0.01 & -0.13 & -1.51 \\
\hline In-degree centrality & $4.77^{*}$ & 2.02 & 0.23 & 2.36 & -0.76 & 2.69 & -0.04 & -0.28 & -0.19 & 2.75 & -0.01 & -0.07 \\
\hline Organic & & & & & $0.24^{* *}$ & * 0.08 & 0.28 & 2.98 & $0.34^{* *}$ & 0.13 & 0.39 & 2.69 \\
\hline Out-degree centrality & & & & & $4.11^{*}$ & 1.71 & 0.31 & 2.40 & $7.73 t$ & 3.95 & 0.59 & 1.96 \\
\hline \multicolumn{5}{|c|}{ Out-degree centrality*organic } & & & & & -1.20 & 1.18 & -0.35 & -1.02 \\
\hline$R^{2}$ & \multicolumn{4}{|c|}{0.19} & \multicolumn{4}{|c|}{0.32} & \multicolumn{4}{|c|}{0.33} \\
\hline$D R^{2}$ & \multicolumn{4}{|c|}{0.19} & \multicolumn{4}{|c|}{0.13} & \multicolumn{4}{|c|}{0.01} \\
\hline$F(d f)$ & \multicolumn{4}{|c|}{$4.37^{* *}(96)$} & \multicolumn{4}{|c|}{$6.30 * *(94)$} & \multicolumn{4}{|c|}{$5.64^{* *}(93)$} \\
\hline
\end{tabular}

${ }^{* * *} p<0.001,{ }^{* *} p<0.01,{ }^{*} p<0.05, p \dagger<0.1$

(1) TABLE 3

Regression analyses results for externa learning as the dependent variable
We were then interested in analyzing whether informal out-degree is positively related to external learning (H2) and if the organic structuring of activities ( $\mathrm{H} 3 \mathrm{~b})$ moderates this relationship. Thus, we conducted separate hierarchical ordinary least squares (OLS) regression by entering the control 
DRUŠ. ISTRAŽ. ZAGREB GOD. 28 (2019), BR. 1, STR. 109-128

SITAR, A. S., BOGILOVIĆ S., PAHOR, $M$. THE RELATIONSHIP..

\section{DISCUSSION}

\section{Theoretical contributions}

Organizational network research, specifically research into knowledge networks (Phelps et al., 2012), recognizes that employees need to establish relationships with their colleagues if they wish to utilize each other's knowledge (Borgatti \& Cross, 2003). However, previous research does not provide sufficient information concerning the relationship between the network characteristics of employees and internal and external learning, the two crucial behaviors in learning organizations contributing to competitive advantage (Shin et al., 2017). Moreover, by combining the structural and behavioral perspective (Brass \& Burkhardt, 1993), we acknowledge that particular learning behaviors are associated with a specific structural position. Our research shows there are substantial differences in network utilization when it comes to internal and external learning. The results also demonstrate that employee internal learning is stimulated by the relevant internal knowledge relationships that they have with their co-workers, whereas external learning is related to informal relationships that distribute knowledge obtained externally within the organization. As such, we first add to the social network literature and organizational learning literature by researching which specific informal network properties (i.e., in-degree and out-degree centrality) commonly used in the organizational-knowledge-sharing-network literature (Carpenter et al., 2012) determine specific learning behavior (i.e., external and internal learning).

Second, we advance the social network literature and its traditional social network theory by claiming that the advantages of social networks are embedded in social positions (Burt, 1986; Wellman \& Berkowitz, 1988). We show that employees can only learn from their internal or external environment if they hold a strong central position (i.e., in-degree 
DRUŠ. ISTRAŽ. ZAGREB GOD. 28 (2019), BR. 1 STR. $109-128$

SITAR, A. S., BOGILOVIĆ, S., PAHOR, $M$.: THE RELATIONSHIP... and out-degree centrality) in the knowledge network. We also add to the social network literature by highlighting the importance of informal relationships and of separately exploring the impacts of in-degree and out-degree centrally. We thus answer a call by Porter and Woo (2015) to explore in more detail how colleagues' perceptions of one another shape informal dyadic relationships.

Third, we contribute to the organizational learning theory by showing that not only strong ties with a more capable peer (Holley, Santos, Cook, \& Kerr, 2016) and participation in internal and external networks (Van Der Heijden, Boon, Van der Klink, \& Meijs, 2009) can stimulate employees' learning, but that holding a central position in knowledge networks is the key to learning behavior. Moreover, with this research we add to previous team-level research on the relationship between centrality and organizational learning (Murray \& Moses, 2005). We show that on the individual level in-degree centrality relates to internal learning and out-degree centrality to external learning. By dividing learning into internal and external employee learning behavior, we further advance the organizational learning theory by providing greater insight into the network properties that support specific employee learning behavior.

Fourth, although our research indicates that the organic structuring of activities does not moderate the proposed relationships, suggesting that informal relationships for sharing externally and internally obtained knowledge are beyond managers' reach, we add to the work design literature which has neglected the fact that network interactions can be a source of learning behavior (Kilduff \& Brass, 2010a). Due to the fact that the structuring of activities represents the design of work on the individual level as part of broader organization and work design (Mintzberg, 1979), this research may be seen as a first step towards exploring how structural properties on the organizational or departmental level (e.g., size, centralization, formalization, number of levels) impact the ways work is designed (Oldham \& Fried, 2016).

\section{Managerial implications}

This paper examines how structural characteristics shape different employee learning behaviors and thus provides managers with a better understanding of the differences in relationships and how they stimulate employees' internal and external learning. As both types of learning are required in learning organizations, managers must implement distinct practices to support each of them by supporting employees in building informal relationships. In particular, supporting commu- 
DRUŠ. ISTRAŽ. ZAGREB GOD. 28 (2019), BR. 1, STR. $109-128$

SITAR, A. S., BOGILOVIĆ, S., PAHOR, $M$. THE RELATIONSHIP..

nities of practice to enable informal knowledge sharing and creating good working environments for employees (Aljuwaiber, 2016) will benefit internal and external learning by obtaining knowledge from co-workers, and by sharing knowledge obtained externally throughout the organization. Managers might also benefit from the finding that the way activities are formally structured does not influence the relationship between one's position in the informal-knowledge-sharing network and the learning behavior of employees.

\section{LIMITATIONS, FUTURE RESEARCH, AND CONCLUSION}

Our research has some important limitations due to the research design, use of cross-sectional data and a single data source, causing common method bias. The first limitation relates to generalizability given that the research was performed in a single organization. We recommend repeating the research in various organizations from different industries for the purpose of comparative analysis. Second, although we incorporated informal relationship and organizational structure as boundary conditions for employee learning (i.e., internal and external), we suggest future research also explore other important network characteristics (ex. structural holes, weak/ strong ties) to provide further insights into the social knowledge network's relationship with employee learning.

The third limitation relates to our research approach. In line with Klein and Kozlowski (2000), we suspect that a top-down multilevel approach would provide a better understanding of the higher-level characteristics influencing lower levels. Moreover, because the competitive environment today means work is constantly shifting between routine and complex tasks, demanding high levels of formalization at certain times and of collaboration at others (Repenning et al., 2018), it would be valuable to investigate how patterns of relationships change over time due to this dynamic work design. We thus encourage future studies to use a multilevel approach (Klein \& Kozlowski, 2000) and/or investigate the proposed relationships longitudinally. It would also be beneficial if research were to tackle the employees' perspective and how they themselves can change their job design to create better outcomes such as learning without changing formal policies and job descriptions (Oldham \& Fried, 2016; Oldham \& Hackman, 2010). Employees' jobs could be redesigned to balance the motivational and organic organizational structure and thereby enhance both satisfaction/learning and efficiency outcomes (Morgeson \& Campion, 2002). Namely, future research that incorporates the employees' perception of their job's design and learning behavior is needed. 
Aiken, M., \& Hage, J. (1971). The organic organization and innovation. Sociology, 5(1), 63-82. https://doi.org/10.1177/003803857100500105

Aljuwaiber, A. (2016). Communities of practice as an initiative for knowledge sharing in business organisations: A literature review. Journal of Knowledge Management, 20(4), 731-748. https://doi.org/10. 1108/JKM-12-2015-0494

Baldwin, T. T., Bedell, M. D., \& Johnson, J. L. (1997). The social fabric of a team-based MBA program: Network effects on student satisfaction and performance. Academy of Management Journal, 40(6), 1369-1397. https://doi.org/10.5465/257037

Bhardwaj, A., Qureshi, I., Konrad, A. M., \& Lee, S. H. (M.) (2016). A two-wave study of self-monitoring personality, social network churn, and in-degree centrality in close friendship and general socializing networks. Group \& Organization Management, 41(4), 526-559. https://doi. org/10.1177/1059601115608027

Borgatti, S. P., \& Cross, R. (2003). A relational view of information seeking and learning in social networks. Management Science, 49(4), 432-445. https://doi.org/10.1287/mnsc.49.4.432.14428

Borgatti, S. P., \& Foster, P. C. (2003). The network paradigm in organizational research: A review and typology. Journal of Management, 29(6), 991-1013. https://doi.org/10.1016/S0149-2063_03_00087-4

Brass, D. J. (1984). Being in the right place: A structural analysis of individual influence in an organization. Administrative Science Quarterly, 29(4), 518-539. https://doi.org/10.2307/2392937

Brass, D. J., \& Burkhardt, M. E. (1993). Potential power and power use: An investigation of structure and behavior. Academy of Management Journal, 36(3), 441-470. https://doi.org/10.5465/256588

Brass, D. J., Galaskiewicz, J., Greve, H. R., \& Tsai, W. (2004). Taking stock of networks and organizations: A multilevel perspective. Academy of Management Journal, 47(6), 795-817. https://doi.org/10.5465/20 159624

Bruns, T., \& Stalker, G. M. (1961). The management of innovation. London: Tavistock.

Burt, R. S. (1986). Comment. In S. Lindberg, J. S. Coleman, \& S. Novak (Eds.), Approaches to social theory (pp. 105-107). New York, NY: Russell Sage.

Burt, R. S. (2004). Structural holes and good ideas. American Journal of Sociology, 110(2), 349-399. https://doi.org/10.1086/421787

Carpenter, M. A., Li, M., \& Jiang, H. (2012). Social network research in organizational contexts: A systematic review of methodological issues and choices. Journal of Management, 38(4), 1328-1361. https://doi. org/10.1177/0149206312440119

Cavaliere, V., Lombardi, S., \& Giustiniano, L. (2015). Knowledge sharing in knowledge-intensive manufacturing firms. An empirical study of its enablers. Journal of Knowledge Management, 19(6), 1124-1145. https://doi.org/10.1108/JKM-12-2014-0538 
DRUŠ. ISTRAŽ. ZAGREB GOD. 28 (2019), BR. 1, STR. $109-128$

SITAR, A. S., BOGILOVIĆ, S., PAHOR, $M$. THE RELATIONSHIP..
Cross, R., \& Cummings, J. N. (2004). Tie and network correlates of individual performance in knowledge-intensive work. Academy of Management Journal, 47(6), 928-937.

Dahlander, L., O'Mahony, S., \& Gann, D. M. (2016). One foot in, one foot out: How does individuals' external search breadth affect innovation outcomes? Strategic Management Journal, 37(2), 280-302. https:// doi.org/10.1002/smj.2342

Davenport, T. H., \& Prusak, L. (1998). Working knowledge: How organizations manage what they know. Boston (Massachusetts): Harvard Business School Press.

Doreian, P., \& Conti, N. (2012). Social context, spatial structure and social network structure. Social Networks, 34(1), 32-46. https://doi. org/10.1016/j.socnet.2010.09.002

Easterby-Smith, M., Lyles, M. A., \& Tsang, E. W. K. (2008). Inter-organizational knowledge transfer: Current themes and future prospects. Journal of Management Studies, 45(4), 677-690. https://doi.org/10.1111/ j.1467-6486.2008.00773.x

Fey, C. F., \& Birkinshaw, J. (2005). External sources of knowledge, governance mode, and R\&D performance. Journal of Management, 31(4), 597-621. https://doi.org/10.1177/0149206304272346

Fiol, C. M., \& Lyles, M. A. (1985). Organizational learning. The Academy of Management Review, 10(4), 803-813. https://doi.org/10.5465/ amr.1985.4279103

Freeman, L. C. (1978). Centrality in social networks conceptual clarification. Social Networks, 1(3), 215-239. https://doi.org/10.1016/03788733(78)90021-7

Granovetter, M. (1985). Economic action and social structure: The problem of embeddedness. American Journal of Sociology, 91(3), 481-510. https://doi.org/10.1086/228311

Han, S.-K. (1996). Structuring relations in on-the-job networks. Social Networks, 18(1), 47-67. https://doi.org/10.1016/0378-8733(95)00255-3

Hansen, M. T. (2002). Knowledge networks: Explaining effective knowledge sharing in multiunit companies. Organization Science, 13(3), 232-248. https://doi.org/10.1287/orsc.13.3.232.2771

Ho, V. T., \& Pollack, J. M. (2014). Passion isn't always a good thing: Examining entrepreneurs' network centrality and financial performance with a dualistic model of passion. Journal of Management Studies, 51(3), 433-459. https://doi.org/10.1111/joms.12062

Hollenbeck, J. R., \& Jamieson, B. B. (2015). Human capital, social capital, and social network analysis: Implications for strategic human resource management. Academy of Management Perspectives, 29(3), 370-385. https://doi.org/10.5465/amp.2014.0140

Holley, D., Santos, P., Cook, J., \& Kerr, M. (2016). "Cascades, torrents \& drowning" in information: Seeking help in the contemporary general practitioner practice in the UK. Interactive Learning Environments, 24(5), 954-967. https://doi.org/10.1080/10494820.2015.1128206

Huang, X., Rode, J. C., \& Schroeder, R. G. (2011). Organizational structure and continuous improvement and learning: Moderating 
DRUŠ. ISTRAŽ. ZAGREB GOD. 28 (2019), BR. 1 STR. $109-128$

SITAR, A. S., BOGILOVIĆ, S., PAHOR, $M$.: THE RELATIONSHIP... effects of cultural endorsement of participative leadership. Journal of International Business Studies, 42(9), 1103-1120. https://doi.org/10.1057/ jibs.2011.33

Huber, G. P. (1991). Organizational learning: The contributing processes and the literatures. Organization Science, 2(1), 88-115. https://doi. org/10.1287/orsc.2.1.88

Ibarra, H. (1992). Homophily and differential returns: Sex differences in network structure and access in an advertising firm. Administrative Science Quarterly, 37(3), 422-447. https://doi.org/10.2307/2393451

Ibarra, H., \& Andrews, S. B. (1993). Power, social influence, and sense making: Effects of network centrality and proximity on employee perceptions. Administrative Science Quarterly, 38(2), 277-303. https:// doi.org/10.2307/2393414

Ibarra, H., Kilduff, M., \& Tsai, W. (2005). Zooming in and out: Connecting individuals and collectivities at the frontiers of organizational network research. Organization Science, 16(4), 359-371. https:// doi.org/10.1287/orsc.1050.0129

Kessler, E. H., Bierly, P. E., \& Gopalakrishnan, S. (2000). Internal vs. external learning in new product development: Effects on speed, costs and competitive advantage. R\&D Management, 30(3), 213-224. https://doi.org/10.1111/1467-9310.00172

Keum, D. D., \& See, K. E. (2017). The influence of hierarchy on idea generation and selection in the innovation process. Organization Science, 28(4), 597-780. https://doi.org/10.1287/orsc.2017.1142

Kilduff, M., \& Brass, D. J. (2010a). Job design: A social network perspective. Journal of Organizational Behavior, 31(2/3), 309-318. https://doi .org/10.1002/job.609

Kilduff, M., \& Brass, D. J. (2010b). Organizational social network research: Core ideas and key debates. Academy of Management Annals, 4(1), 317-357. https://doi.org/10.5465/19416520.2010.494827

Kilduff, M., \& Krackhardt, D. (1994). Bringing the individual back in: A structural analysis of the internal market for reputation in organizations. Academy of Management Journal, 37(1), 87-108. https://doi.org/ $10.5465 / 256771$

Klein, K. J., \& Kozlowski, S. W. J. (2000). From micro to meso: Critical steps in conceptualizing and conducting multilevel research. Organizational Research Methods, 3(3), 211-236. https://doi.org/10.1177/1094 42810033001

Klein, K. J., Lim, B.-C., Saltz, J. L., \& Mayer, D. M. (2004). How do they get there? An examination of the antecedents of centrality in team networks. Academy of Management Journal, 47(6), 952-963. https:// doi.org/10.5465/20159634

Krackhardt, D. (1992). The strength of strong ties: The importance of philos in organizations. In N. Nohria \& R. G. Eccles (Eds.), Networks and organizations: Structure, form, and action (pp. 216-239). Boston, MA: Harvard Business School Press.

Lazega, E. (1992). The micropolitics of knowledge: Communication and indirect control in workgroups. New York: Aldine de Gruyter. 
DRUŠ. ISTRAŽ. ZAGREB GOD. 28 (2019), BR. 1, STR. $109-128$

SITAR, A. S., BOGILOVIĆ S., PAHOR, $M$. THE RELATIONSHIP..
Levitt, B., \& March, J. G. (1988). Organizational learning. Annual Review of Sociology, 14, 319-340. https://doi.org/10.1146/annurev.so.14. 080188.001535

Martínez-León, I. M., \& Martínez-García, J. A. (2011). The influence of organizational structure on organizational learning. International Journal of Manpower, 32(5/6), 537-566. https://doi.org/10.1108/0143772 1111158198

Mintzberg, H. (1979). The structuring of organization: A synthesis of the research. Englewood Cliffs, NJ: Prentice Hall.

Morgeson, F. P., \& Campion, M. A. (2002). Minimizing tradeoffs when redesigning work: Evidence from a longitudinal quasi-experiment. Personnel Psychology, 55(3), 589-612. https://doi.org/10.1111/j.17446570.2002.tb00122.x

Murray, P., \& Moses, M. (2005). The centrality of teams in the organisational learning process. Management Decision, 43(9), 1186-1202. https://doi.org/10.1108/00251740510626263

Nonaka, I., \& Takeuchi, H. (1995). The knowledge-creating company: How Japanese companies create the dynamics of innovation. New York: Oxford University Press.

Oldham, G. R., \& Fried, Y. (2016). Job design research and theory: Past, present and future. Organizational Behavior and Human Decision Processes, 136, 20-35. https://doi.org/10.1016/j.obhdp.2016.05.002

Oldham, G. R., \& Hackman, J. R. (2010). Not what it was and not what it will be: The future of job design research. Journal of Organizational Behavior, 31(2/3), 463-479. https://doi.org/10.1002/job.678

Parker, S. K. (2014). Beyond motivation: Job and work design for development, health, ambidexterity, and more. Annual Review of Psychology, 65(1), 661-691. https://doi.org/10.1146/annurev-psych-010213115208

Phelps, C., Heidl, R., \& Wadhwa, A. (2012). Knowledge, networks, and knowledge networks: A review and research agenda. Journal of Management, 38(4), 1115-1166. https://doi.org/10.1177/0149206311432640

Porter, C. M., \& Woo, S. E. (2015). Untangling the networking phenomenon: A dynamic psychological perspective on how and why people network. Journal of Management, 41(5), 1477-1500. https://doi. org/10.1177/0149206315582247

Pugh, D. S. (2003). The measurement of organization structure. In M. J. Handel (Ed.), The sociology of organizations: Classic, contemporary and critical readings (pp. 66-75). Thousand Oaks: SAGE Publications.

Pugh, S., Hickson, D. J., Hinings, C. R., \& Turner, C. (1968). Dimensions of organization structure. Administrative Science Quarterly, 13(1), 65-105. https://doi.org/10.2307/2391262

Reagans, R., \& McEvily, B. (2003). Network structure and knowledge transfer: The effects of cohesion and range. Administrative Science Quarterly, 48(2), 240-267. https://doi.org/10.2307/3556658

Reagans, R., \& Zuckerman, E. W. (2001). Networks, diversity, and productivity: The social capital of corporate $R \& D$ teams. Organization Science, 12(4), 502-517. https://doi.org/10.1287/orsc.12.4.502.10637 
DRUŠ. ISTRAŽ. ZAGREB GOD. 28 (2019), BR. 1, STR. $109-128$

SITAR, A. S., BOGILOVIĆ S., PAHOR, $M$.: THE RELATIONSHIP...
Reinholt, M. I. A., Pedersen, T., \& Foss, N. J. (2011). Why a central network position isn't enough: The role of motivation and ability for knowledge sharing in employee networks. Academy of Management Journal, 54(6), 1277-1297. https://doi.org/10.5465/amj.2009.0007

Repenning, N. P., Kieffer, D., \& Repenning, J. (2018). A new approach to designing work. MIT Sloan Management Review, 59(1), 29-38. Available at https://sloanreview.mit.edu/article/a-new-approach-todesigning-work/

Shin, H. W., Picken, J. C., \& Dess, G. G. (2017). Revisiting the learning organization: How to create it. Organizational Dynamics, 46(1), 46-56. https://doi.org/10.1016/j.orgdyn.2016.10.009

Simon, H. A. (1991). Bounded rationality and organizational learning. Organization Science, 2(1), 125-134. https://doi.org/10.1287/orsc.2.1.125

Sitar, A. S., Pahor, M., \& Škerlavaj, M. (2018). Learning-structure fit part II: Empirical examination of the relationship between employee learning and formalization, specialization and standardization of work. The Learning Organization, 25(6), 370-382. https://doi.org/10. 1108/TLO-02-2017-0022

Slater, S. F., \& Narver, J. C. (1995). Market orientation and the learning organization. Journal of Marketing, 59(3), 63-74. https://doi.org/10. 1177/002224299505900306

Stam, W., \& Elfring, T. (2008). Entrepreneurial orientation and new venture performance: The moderating role of intra- and extraindustry social capital. Academy of Management Journal, 51(1), 97-111. https:// doi.org/10.5465/amj.2008.30744031

Tsai, W. (2001). Knowledge transfer in intraorganizational networks: Effects of network position and absorptive capacity on business unit innovation and performance. Academy of Management Journal, 44(5), 996-1004. https://doi.org/10.5465/3069443

Tsai, W., \& Ghoshal, S. (1998). Social capital and value creation: The role of intrafirm networks. Academy of Management Journal, 41(4), 464-476. https://doi.org/10.5465/257085

Van Der Heijden, B., Boon, J., Van der Klink, M., \& Meijs, E. (2009). Employability enhancement through formal and informal learning: An empirical study among Dutch non-academic university staff members. International Journal of Training and Development, 13(1), 19-37. https://doi.org/10.1111/j.1468-2419.2008.00313.x

Vera, D., \& Crossan, M. (2004). Strategic leadership and organizational learning. Academy of Management Review, 29(2), 222-240. https:// doi.org/10.5465/amr.2004.12736080

Wang, S., \& Noe, R. A. (2010). Knowledge sharing: A review and directions for future research. Human Resource Management Review, 20(2), 115-131. https://doi.org/10.1016/j.hrmr.2009.10.001

Wellman, B., \& Berkowitz, S. D. (Eds.) (1988). Social structures: A network approach. New York, NY: Cambridge University Press.

Winter, S. (1994). Organizing for continuous improvement: Evolutionary theory meets the quality revolution. In J. A. Baum \& J. V. Singh (Eds.), Evolutionary dynamics of organizations (pp. 90-108). New York: Oxford University Press. 
DRUŠ. ISTRAŽ. ZAGREB GOD. 28 (2019), BR. 1, STR. 109-128

SITAR, A. S., BOGILOVIĆ, S., PAHOR, $M$. THE RELATIONSHIP..
Odnos između neformalne mreže dijeljenja znanja $\mathrm{i}$ individualnog učenja u organizacijama: koliko je važno strukturiranje aktivnosti?

Aleša Saša SITAR

Ekonomski fakultet, Ljubliana

Sabina BOGILOVIĆ

Fakultet za upravu, Ljubliana

Marko PAHOR

Ekonomski fakultet, Ljubljana

Na temelju teorije organizacijskih mreža istražen je odnos između obilježja neformalne mreže dijeljenja znanja (unutarnji i vanjski stupani centralnosti) i stupnja unutarnjeg i vanjskog učenja kod zaposlenika. Specifično, rad ispituje razlike $u$ upotrebi mreže dijeljenja znanja u situaciji kad zaposlenici uče iz unutarnjeg ili vanjskog izvora te istražuje moderatorski utjecaj percipiranoga organskog strukturiranja aktivnosti. Rezultati pokazuju da se zaposlenici koriste neformalnim unutarnjim vezama za interno učenje, odnosno oslanjaju se na neformalne vanjske veze za vanjsko učenje i diseminaciju znanja. Očekivana moderirajuća uloga organskoga strukturiranja aktivnosti nije potvrđena, što nudi važne implikacije za teoriju i praksu.

Ključne riječi: neformalna mreža dijeljenja znanja, unutarnje učenje, vanjsko učenje, organsko strukturirane aktivnosti

\section{(c) (i) (5)}

Međunarodna licenca / International License:

Imenovanje-Nekomercijalno/ Attribution-NonCommercial 